University of Nebraska - Lincoln

DigitalCommons@University of Nebraska - Lincoln

$6-2006$

\title{
Lists of Potential Hydrophytes for the United States: A Regional Review and their Use in Wetland Identification
}

\author{
Ralph W. Tiner \\ U.S. Fish and Wildlife Service
}

Follow this and additional works at: https://digitalcommons.unl.edu/usfwspubs

Part of the Aquaculture and Fisheries Commons

Tiner, Ralph W., "Lists of Potential Hydrophytes for the United States: A Regional Review and their Use in Wetland Identification" (2006). US Fish \& Wildlife Publications. 24.

https://digitalcommons.unl.edu/usfwspubs/24

This Article is brought to you for free and open access by the US Fish \& Wildlife Service at DigitalCommons@University of Nebraska - Lincoln. It has been accepted for inclusion in US Fish \& Wildlife Publications by an authorized administrator of DigitalCommons@University of Nebraska - Lincoln. 
NOTE

\title{
LISTS OF POTENTIAL HYDROPHYTES FOR THE UNITED STATES: A REGIONAL REVIEW AND THEIR USE IN WETLAND IDENTIFICATION
}

\author{
Ralph W. Tiner \\ U.S. Fish and Wildlife Service \\ National Wetlands Inventory Program, Northeast Region \\ 300 Westgate Center Drive \\ Hadley, Massachusetts, USA 01035 \\ E-mail: ralph_tiner@fws.gov
}

\begin{abstract}
The U.S. federal government has developed lists of plant species that occur in wetlands. The initial purpose of these lists was to enumerate plants that grow in wetlands and that could be used to identify wetlands according to the U.S. Fish and Wildlife Service's wetland classification system. The first list was generated in 1976 by the Service, and since that time, the list has undergone several iterations as more information was reviewed or became available through field investigations and scientific research. Two lists are currently published and available for use: a 1988 list and a 1996 draft list. The latter list represents an improvement based on nearly 10 years of field work by the four signatory agencies plus comments from other agencies, organizations, wetland scientists, and others. The national list was generated from 13 regional lists. These data have not been summarized previously; this note provides an interregional summary of vital statistics. The 1988 list included 6,728 species, while the 1996 list has nearly 1,000 additions for a total of 7,662 species (a 14\% increase). Roughly one-third of the nation's vascular plants have some potential for being hydrophytes - plants growing in water or on a substrate that is at least periodically deficient in oxygen due to excessive wetness. Each species on the list is assigned an indicator status reflecting its frequency of occurrence in wetlands: 1) obligate (OBL; $>99 \%$ of time in wetlands), 2) facultative wetland (FACW; 67$99 \%$ in wetlands), 3) facultative (FAC; 34-66\%), 4) facultative upland (FACU; 1-33\%), and 5) upland (UPL; <1\%). From 1988 to 1996 , the regional lists of potentially hydrophytic species increased by more than 39 percent in three regions: Caribbean, North Plains, and Central Plains. The percent of OBL, FACW, and FAC species on the lists decreased in the Northeast and Hawaii. The percent of OBL and FACW species also decreased in the Southeast and Northwest. The number of OBL species declined in all but three regions, whereas the number of FACU species added to the lists increased in all regions except Hawaii. The regional "wetland plant" lists have been used to help identify plant communities that possess a predominance of wetland indicator plants (i.e., a positive indicator of hydrophytic vegetation) and to identify wetlands that can be recognized solely based on their vegetation.
\end{abstract}

Key Words: $\quad$ wetland plant lists, hydrophytes, hydrophytic vegetation, wetland ecotypes, National Wetlands Inventory, prevalence index, wetland identification, wetland delineation

\section{INTRODUCTION}

When the U.S. Fish and Wildlife Service (FWS) initiated its National Wetlands Inventory Program (NWI) in the mid-1970s, one of the first tasks was to develop a wetland classification system to serve as the standard for mapping wetlands across the country. The classification system went through a few versions and field testing prior to its publication as "Classification of Wetlands and Deepwater Habitats of the United States"' (Cowardin et al. 1979). This classification system has been used for wetland mapping for over 25 years. On December 17, 1996, it was adopted by the Federal Geographic Data Committee as the national technical standard for wetland classification (FGDCSTD-004) when reporting on wetland status and trends and for geospatial data entered into the national geospatial database (http://www.fgdc.gov/standards/status/ swgstat.html; http://www.nwi.fws.gov/fgdc/certificate. pdf). The FWS's wetland definition listed the predominance of hydrophytes and undrained hydric soils as two main indicators of wetlands. Moreover, the document referenced that the FWS was preparing a list of "hydrophytes and other plants occurring in wetlands of the United States."

The initial list compiled in March 1976 by the FWS contained only 1,626 species and was considered "ob- 


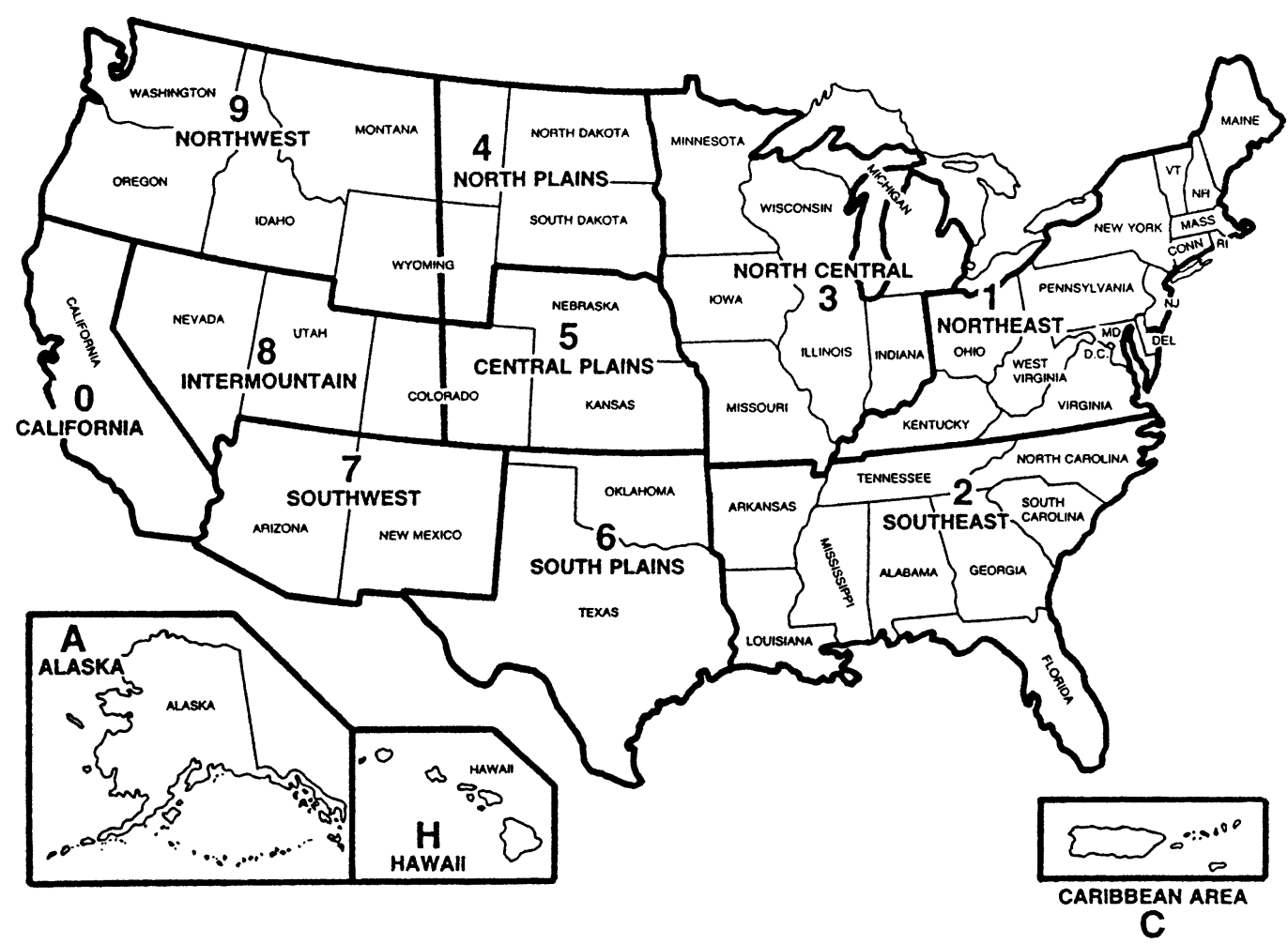

Figure 1. Map showing regions used to identify wetland indicator status of U.S. plant species (Reed 1988).

viously incomplete' and 'especially deficient in plant species from the western United States, Alaska, the Caribbean, and Hawaii' (Reed 1988). After further review by other scientists and the formation of national and regional plant panels (with members from the FWS, the U.S. Army Corps of Engineers, the Environmental Protection Agency, and the U.S.D.A. Soil Conservation Service), the list was expanded to 4,235 species by 1977 , to 5,244 in 1982 , to 6,042 in 1986 , and to 6,728 in 1988 . The national list of "plant species that occur in wetlands" is composed of thirteen regional lists (Figure 1). The basic purpose of the lists was to aid in using plants to identify wetlands for a national inventory of wetlands. Plants represented on the "wetland plant lists" are "species that have demonstrated an ability (presumably because of morphological and/or physiological adaptations and/or reproductive strategies) to achieve maturity and reproduce in an environment where all or portions of the soil within the root zone become, periodically or continuously, saturated or inundated during the growing season' (Reed 1988). The lists do not include plants incapable of growing under these conditions such as those that grow in wetlands only during droughts or prolonged drawdowns, or strictly on nonhydric microsites.

Rather than prepare simple lists of all the species, the FWS recognized that some plants on the lists were always associated with wetlands, while others occurred in both wetlands and uplands (dryland) to varying degrees. Consequently, the FWS established five basic categories of "wetland indicator status" reflecting different frequencies of occurrence in wetlands: 1) obligate (OBL; $>99 \%$ of time in wetlands), 2) facultative wetland (FACW; 67-99\% in wetlands), 3) facultative (FAC; 34-66\%), 4) facultative upland (FACU; 1$33 \%$ ), and 5) upland (UPL; $<1 \%$ ). The latter species were typically not recorded on the regional and national lists as the lists represent plants occurring in wetlands; some UPL species appear on the lists because they occur in wetlands $>1 \%$ of the time in one region of the country or simply to show that they had been reviewed. For the "facultative" type species, a + (plus) or a - (minus) representing the higher or lower end of the range of occurrence in wetlands was assigned to species where there were differences in opinions among the reviewers and/or regional panel members (Reed 1988). The ranges for + and - species were not specifically defined. No indicator (NI) was assigned to species with insufficient information available to project their indicator status, whereas species designated with "NA" were those where differences among reviewers could not be resolved. An asterisk (*) was given to species to indicate a tentative status pending further review. The publication emphasized that the wetland indicator status "should not be equat- 
Table 1. The 11-step process for finalizing the national wetland plant list established per interagency agreement in June 1996 (Reed 1997).

1. Regional panels prepare updated draft of regional wetland plant list.

2. Regional panels submit proposed changes to the national panel and identify changes that have potentially significant impact for wetland identification and/or delineation in the region.

3. The national panel proposes changes in close consultation with regional panels.

4. The national panel makes changes/deletions/corrections as needed based on their review and in consultation with regional panels. Agency representatives will inform appropriate headquarters officials in their respective agencies on the status of the effort during all phases of the process including a briefing by the national panel.

5. The FWS prepares a draft national list and prepares a notice of availability in the Federal Register for public review and comment.

6. Public comments go to the FWS and the national panel will evaluate to determine which merit scientific review and input.

7. Scientific comments are submitted to regional panels for draft responses and clarification of any discrepancies.

8. The national panel, working with the regional panels, reviews the comments and regional responses, resolves differences, and prepares responses.

9. The Ecology Section of the National Wetlands Inventory Center summarizes all responses at each stage and presents the final national list to the national panel; the national panel members will inform appropriate headquarters officials on the status and effects of the effort.

10. Final technical determinations and the effects of those determinations are provided to each agency headquarters by respective national panel members.

11. The FWS, as chair of the national panel, summarizes all national and regional panel responses and prepares a notice of availability in the Federal Register for the final revised national list.

ed to degrees of wetness" and gave the example of the FACU status including species where a portion of their gene pool occurred exclusively in wetlands (wetland ecotypes) (Reed 1988).

Each species was assigned a wetland indicator status for a particular geographic region since a species occurrence in wetlands may vary regionally. The wetland indicator status was initially based on a review of the literature (e.g., regional flora), then peer-reviewed by regional experts, with final review and resolution of contrasting expert opinions performed by regional interagency plant panels. Over 140 ecologists and botanists have reviewed the lists (Reed 1988). Use of the lists is determined by respective agencies and other users.

During the 1980s, the Corps and the Environmental Protection Agency were developing manuals to help people identify the limits of "jurisdictional" wetlands subject to the Clean Water Act (Environmental Laboratory 1987, Sipple 1988, Federal Interagency Committee for Wetland Delineation 1989). These manuals made use of the wetland plant lists for identifying "'hydrophytic vegetation.', Rather than recognize that all species on the lists do at least sometimes occur as '"hydrophytes,', the manuals identified some species as "wetland indicators" and others as "non-indicators," although there were varying levels of guidance given for recognizing the latter species as hydrophytic vegetation when they occurred on undrained hydric soils or soils with strong indicators of wetland hydrology (see Tiner 1991 for a review of the concept of a hydrophyte).

The regulatory use of these lists has significantly affected updating of the lists, since changes in "wetland indicator status" of some species could potentially change the extent of "jurisdictional", wetlands as they are currently defined by the regulatory agencies. In the 1990s, the regional interagency panels were developing regional supplements to update the list and ratings of some species based on public input since 1988. A supplement for the Northwest region was published in 1993 (Reed et al. 1993), but when the Northeast supplement was released in 1995 (Tiner et al. 1995), there was much concern over the regulatory implications of the changes in the wetland status of a few species, most notably loblolly pine (Pinus taeda L.; FAC- to FAC*), a dominant tree in both wet and dry flatwoods on the coastal plain that is also commercially planted. To ensure improved intra-agency coordination and more opportunities for public review, the four agencies subsequently agreed to an 11-step process for refining the national and regional lists (Table 1). Another objective of this agreement was that new national lists would be produced every five years (Federal Register 62(12): 2680-2681).

Rather than continue production of regional supplements, the FWS in conjunction with the cooperating agencies decided to update the entire list. A revision of the national list based on regional supplements that had been developed previously was published for review and comment in 1996 (U.S. Fish and Wildlife Service 1996, Reed 1997), and an official Federal Register request for comments was announced on January 17, 1997 (Federal Register 62(12): 2680-2681). Two of the 13 original regions had some subregions identified to reflect better the intraregional ecological variability of plant species (Northeast: Coastal Plain, Lower Coastal Plain, Seaboard Lowlands, St. Lawrence-Lake Champlain Plain, and Great Lakes Plain; Southeast: Coastal Plain, Mountains, Florida, and the Florida Keys). Scientific nomenclature was revised to follow Kartesz (1994). A 1998 version incorporating review comments is now undergoing review of scientific plant names based on the latest advances in plant taxonomy.

The purpose of this note is to present summary in- 
formation on the number of species that are potential hydrophytes in various regions of the U.S. since this has not been accomplished to date. It will also discuss some applications of the lists for identifying hydrophytic vegetation and wetlands. Copies of the national and regional lists are available online at: http:// wetlands.fws.gov/plants.htm. The lists have always been open for public review and comment, and the FWS has encouraged submission of comments, especially on NI species that currently lack an indicator status.

\section{THE NATIONAL LIST}

According to the 1988 national list, 6,728 species occur in wetlands more than one percent of the time (Reed 1988). This amounts to roughly one-third of the nation's vascular plants $(21,139$ species in all U.S. states or 22,944 species including Puerto Rico and the U.S Virgin Islands; Misako Nishirno, pers. comm. 2005). Therefore, about two-thirds of the U.S. vascular plant species are not potential hydrophytes according to the 1988 list. The 1996 list included 7,662 species (Andrew Cruz, pers. comm. 2005), so nearly 1,000 species were added to the list (a 14\% increase). Most of the additions were not assigned a wetland indicator status as limited data were available.

\section{REGIONAL LISTS}

Regional Number of Hydrophytic Species

The number of potentially hydrophytic species varied from a high of more than 3,000 in the Southeast to a low of about 1,000 in Alaska and Hawaii, with the apparently incomplete 1988 Caribbean list having the fewest species (Table 2). The Southeast list had the greatest number of species in each wetland indicator status category, with the lone exception of FACU species on the 1988 list (second-place). It had over 100 more obligate species than the next ranked region (Northeast) and nearly 300 more than the next two regions (North Central and California). For FACW species, the Southeast Region had about 200 more species than the second-ranked Northeast. The South Plains had fairly high numbers of FACW and FAC species, ranking third and second, respectively.

\section{Percent Hydrophytic Species}

Alaska has the highest percent of its vascular flora represented by potential hydrophytes, with more than 60 percent of the flora found in wetlands more than one percent of the time (Table 3). According to the 1988 lists, three regions had less than 30 percent of their flora found in wetlands: Caribbean (22.1\%), Southwest $(25.3 \%)$, and California $(27.1 \%)$. Considering the 1996 list, only one region (Southwest) fell in this category.

The percent of the region's vascular flora that are OBL varied from a low of 6.1 percent for Hawaii (1996 list) to a high of 15.6 percent for Alaska (1988 list). The eastern U.S. (Regions 1, 2, and 3) had from 10 to 14 percent of their flora rated as OBL. Alaska led in the percent that were FACW and FAC species as well. Regions 2, 3, and $\mathrm{C}$ had about 10 percent of their flora listed as FACW, while Regions 2, 6, C, and $\mathrm{H}$ had 10 to 13 percent rated as FAC. The North Central and North Plains had the highest percent of FACU species on the list (roughly 10\%).

When considering only hydrophytic species, five regions had nearly 30 percent of their potentially hydrophytic species rated as OBL (Regions $0, \mathrm{C}, 1,2$, and 3 ) on the 1988 list (Table 4). The percent of OBL species dropped for all regions in 1996, due largely to an increase in the number of species placed on the list as NI (no indicator status assigned). Nearly half of the wetland flora was classified as OBL and FACW species (plants with a greater frequency of occurrence in wetlands than in nonwetlands) for seven regions $(1,2$, $3,6,0$, A, and C). California had about 54 percent of its wetland flora rated as OBL and FACW. Hawaii and the Intermountain Region had the highest percent of FACU species on the list, with three other regions (1, 2 , and 3 ) having 20 percent of their potentially hydrophytic species rated as FACU. Several regions had more than 20 percent of the 1996 listed species designated as NI, with North Plains and Central Plains having 36-40 percent in this category.

\section{Changes in the Lists}

Field experiences by the four sponsoring agencies and others since the 1988 list was published led to the addition of many species to the 1996 list of potential hydrophytes for all regions and to changes in the indicator status of some species. All regions except Alaska added more than 100 species to their lists, with the greatest gain coming from NI species for all regions except California, which had its largest increase in FACU species (Table 5). The NI species are plants that have been seen often enough in wetlands to add to the list, but data are limited, so an indicator status was not assigned. The Caribbean, North Plains, and Central Plains lists posted the largest gains, each with more than a 39 percent increase. The list of potentially hydrophytic species for the Caribbean nearly doubled, adding about 100 OBL species, 171 FACW species, 163 FAC species, 32 FACU species, and 152 NI species. These gains were the largest among all regions, 




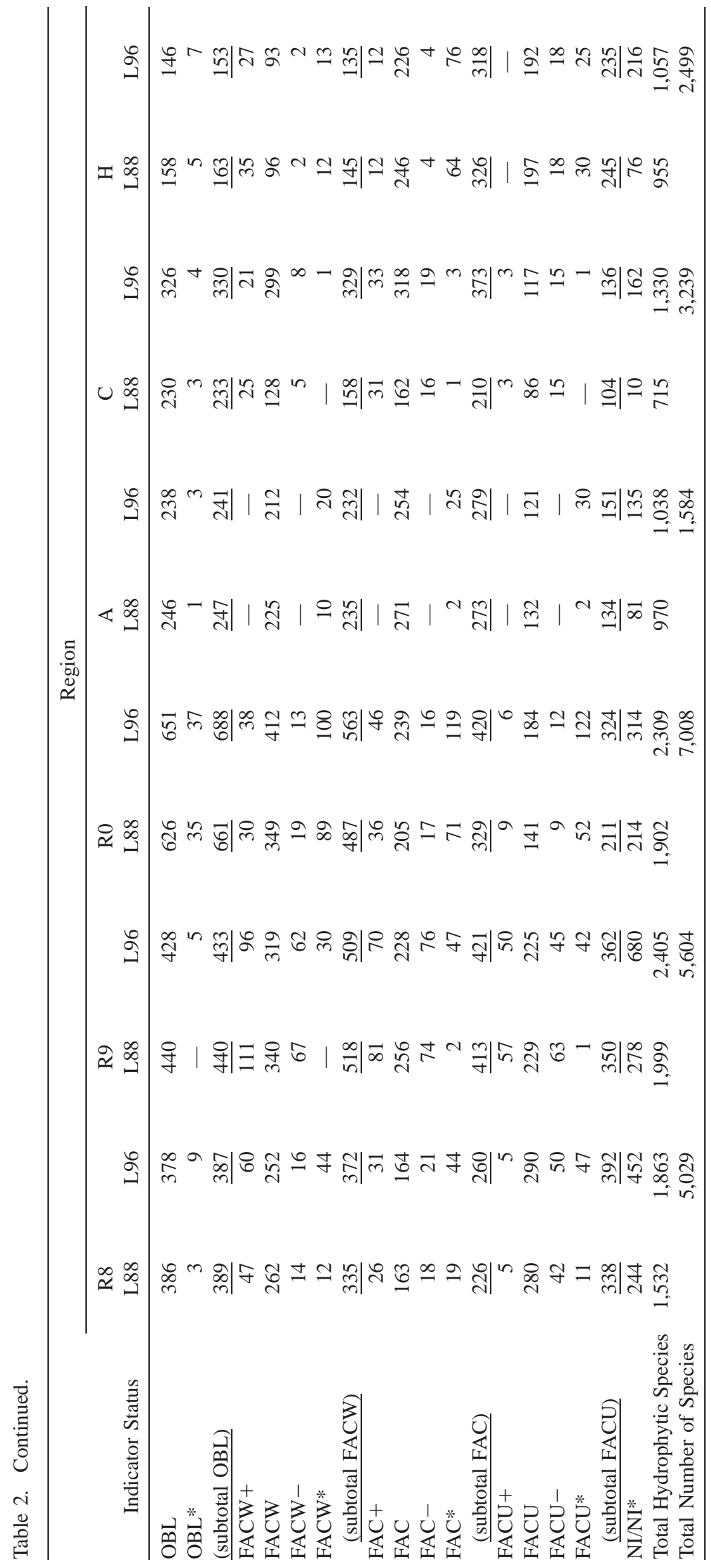




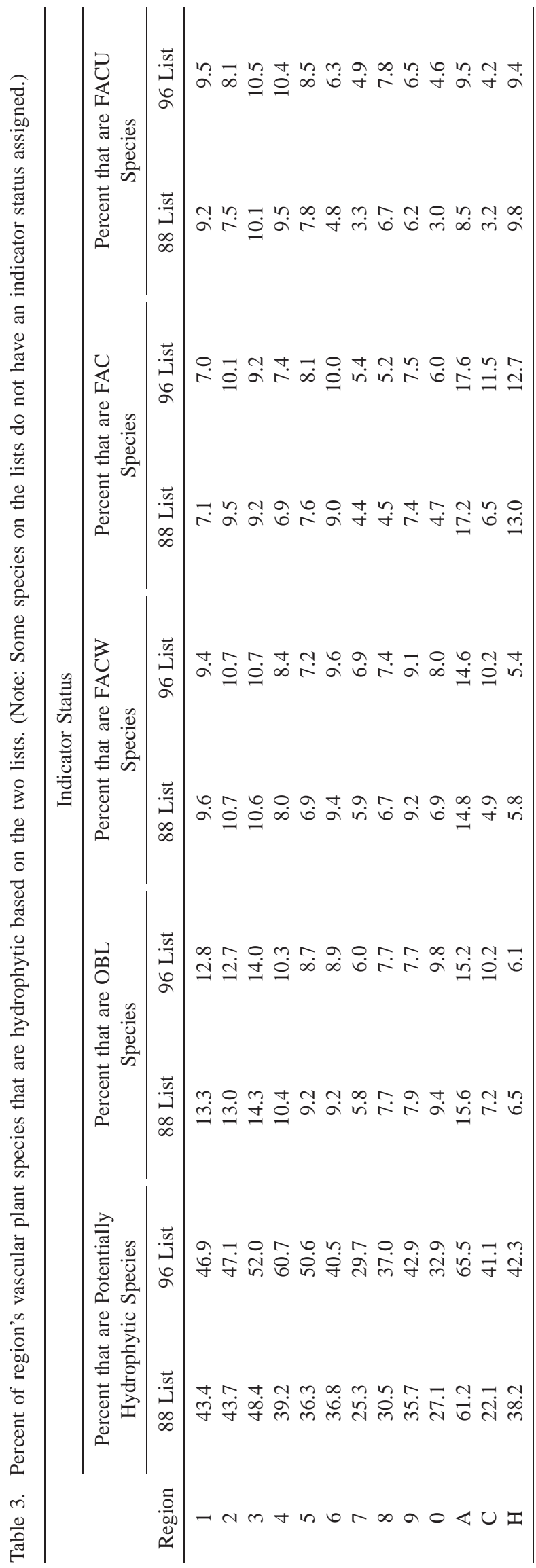

except for FACU species. The percent of OBL, FACW, and FAC species decreased for two regions: Northeast and Hawaii, while the percent of OBL and FACW also decreased for the Southeast and Northwest. The number of OBL species dropped in all regions except the Southwest, California, and Alaska. Most regions had gains in the numbers of FACW species, with exceptions being the Northeast, Southeast, Pacific Northwest, Alaska, and Hawaii. FAC species increased in all regions except the Northeast, North Central, and Hawaii. The number of FACU species increased for all regions except Hawaii.

\section{USE OF THE LISTS FOR IDENTIFYING HYDROPHYTES, HYDROPHYTIC VEGETATION, AND WETLANDS}

First, it should be recognized that all plants on the list are potentially hydrophytes. At the species level, plants do not have the exact same environmental requirements for growth and reproductive success. Individual populations may differ in their tolerance or adaptability to waterlogging or flooding (Tiner 1991). It is widely known that plant species contain ecotypes-populations or groups of populations having genetically-based morphological properties and/or physiological mechanisms that allow them to colonize environments with unique stresses (e.g., wetness/anaerobiosis, salinity, alkalinity, or arid climates) successfully. Such populations are usually prevented from natural interbreeding by ecological barriers (Turesson 1922 a, b, Daubenmire 1968, Barbour et al. 1980, Tiner 1991). Wetland ecotypes are populations of a species that are better adapted for occupying wetlands than other populations of the same species. In fact, renowned plant ecologist Braun-Blanquet (1932) said "the most exact indicators are often, indeed, not the 'good Linnaean species' but rather the elementary species or races, the 'ecotypes' of Turesson (1925) . . . for these forms require more narrowly circumscribed life conditions and, therefore, are socially more sharply specialized." Turesson was one of the pioneers of "ecological genetics," recognizing that habitat-correlated genetic variation was commonplace among plant species (Lowe et al. 2004). Consequently, when using plants as indicators of wetlands, investigators must acknowledge the presence of wetland ecotypes within species, especially for the species that generally grow in drier conditions. Tiner (1999) gave some examples of FACU species that are commonly found in Northeast wetlands. These plants could be wetland ecotypes or simply species with broad wetness tolerances (i.e., ecological plasticity). It is important to emphasize that dry-site indicator plants (i.e., FACU and UPL species) growing in a "wetland area" are not necessarily wet- 
land ecotypes or specially-adapted individuals. Wetlands often contain elevated sites with nonhydric soils, and in some instances, they form a complex wetlandupland mosaic with the "area" actually represented by two intermingled plant communities and soil types - one hydrophytic with hydric soils and the other not. Although some investigators may be inclined to call such plants part of the "wetland" community, these individuals are not growing under wetland conditions and are not hydrophytic or wetland ecotypes. They are simply upland plants that have found relatively dry conditions for establishment within an area dominated by wetland. For wetland delineation purposes, the two plant communities should be treated separately, which makes for a challenging assessment.

The development of the so-called "wetland plant lists" made it easy to see the variety of plants that grow in wetlands. Based on their expected frequency of occurrence in wetlands alone, the OBL species clearly have the greatest affinity for wetlands and are the best vegetative indicators of wetlands, while the FACW species are also quite reliable indicators since they occur in wetlands more than two-thirds of the time. Unfortunately, the lists have been often used in a way that, in large part, has generally eliminated FAC- and FACU species from consideration as hydrophytes. This was clearly not the intent of the lists. All species on the lists are hydrophytes at one time or another, and the indicator status reflects the likelihood that a given individual of a species is a hydrophyte or a certain population of these plants is hydrophytic. While OBL and FACW species are the most reliable plant indicators of wetlands, FAC and FACU species also contain populations of hydrophytes.

To use the lists for identifying wetlands, the FWS funded a North Carolina State University study (Wentworth and Johnson 1986) that reviewed and tested existing methods using indexing or weighted averages for vegetation analysis (including Michener 1983). From this investigation, a weighted averages method was developed for using the wetland indicator statuses of all species in a community to determine its likelihood of being a wetland based on vegetation. Plant species are weighted by their wetland indicator status $(\mathrm{OBL}=1.0, \mathrm{FACW}=2.0, \mathrm{FAC}=3.0, \mathrm{FACU}=4.0$, and UPL $=5.0$ ) and by either the number of points at which they were observed along transects or by their percent cover within a sample plot. Such analyses produce a "prevalence index" score for a plant community between 1.0 and 5.0 reflecting its wetland potential, with a score of 3.0 being a convenient breakpoint separating wetlands from uplands (Wentworth and Johnson 1986, Wentworth et al. 1988). Where the prevalence index is $<2.0$ or $>4.0$, the area has a high probability of being a wetland or upland, respectively, 


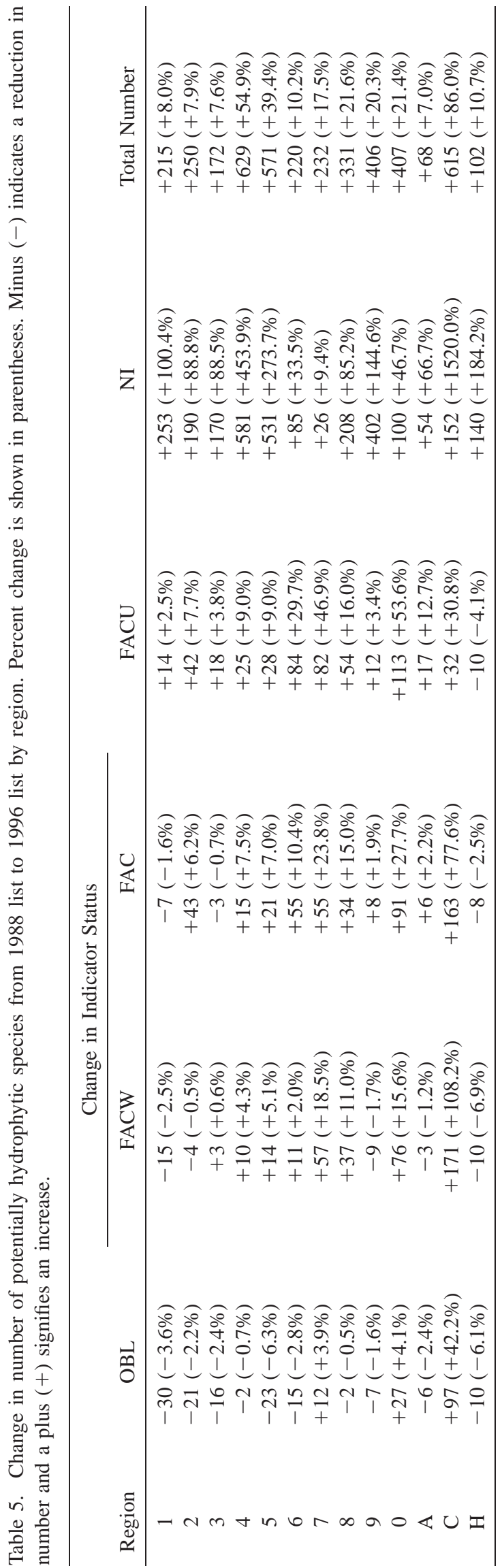

based on vegetation alone. For scores in between, additional data on soils and/or hydrology are recommended to make a wetland or nonwetland determination. A summary and sample applications of this method are found in Tiner (1999). The federal interagency wetland delineation manual included this approach in its recommended methods (Federal Interagency Committee for Wetland Delineation 1989).

The primary indicators method (PRIMET) developed for rapid assessment of wetlands (e.g., for verifying the presence of wetlands for mapping projects) makes use of the wetland indicator statuses from the plant lists (Tiner 1993). It recognizes seven vegetation indicators and 11 soil indicators that are unique to wetlands and could be used independently to verify the presence of a wetland and the location of its boundary. Among the vegetation indicators of wetland are three that reference wetland indicator status: 1) OBL species comprise $>50$ percent of the abundant species in a plant community (an abundant species has $\geq 20 \%$ areal cover), 2) OBL and FACW species comprise $>50$ percent of the abundant species of a plant community, and 3) OBL perennial species collectively represent at least 10 percent areal cover in the plant community and are evenly distributed throughout the community and not restricted to depressional microsites.

For regulatory purposes, following guidance from the Corps manual (Environmental Laboratory 1987, Williams 1992), plant communities where $>50 \%$ of the dominant species (from all strata combined) have an indicator status of FAC or wetter (excluding FAC-) are recognized as a positive indicator of "hydrophytic vegetation.' "Positive indicator' should be emphasized, as such an assemblage of plants can only be considered "hydrophytes" when they are growing in water or on undrained or partly drained hydric soils (not effectively drained hydric soils). Communities that do not meet the basic rule may still be considered positive indicators of hydrophytic vegetation if they meet one of the Corps manual's secondary rules: 1) plants possess morphological, reproductive, or known physiological adaptations for life in saturated soils, 2) plants observed growing in areas flooded and/or saturated for $>10 \%$ of the growing season, and 3) plants are hydrophytic based on professional judgment supported by scientific literature. Number 1 may be useful for identifying FACU species with shallow root systems, hypertrophied lenticels, aerenchyma tissue, adventitious roots, or other morphological adaptations as hydrophytic species, especially when growing on hydric soils (Table 6). Number 2 is not particularly useful, as site visits are limited and one could only get this type of information by making numerous visits or conducting extensive hydrologic studies. Number 3 is useful but puts the onus on the investigator as well as 
Table 6. Plant adaptations for life in wetlands that are useful for identifying hydrophytes in the field. (See Tiner 1993 for discussion.) These adaptations are most useful for identifying FACand drier species as hydrophytes when delineating wetlands. Some of these adaptations may not be useful for tropical wetlands; more study is needed for these systems.

\begin{tabular}{|c|c|}
\hline $\begin{array}{l}\text { Morphological } \\
\text { Adaptations }\end{array}$ & Other Adaptations \\
\hline Shallow root system* & Oxidized rhizospheres \\
\hline Adventitious roots* & Viviparous seedlings \\
\hline \multicolumn{2}{|l|}{ Stem hypertrophy } \\
\hline Aerenchyma tissue* & Other Observations \\
\hline \multicolumn{2}{|l|}{ Hollow stems* } \\
\hline Pneumatophores & $\begin{array}{l}\text { Growing in shallow water } \\
\text { with OBL species*** }\end{array}$ \\
\hline Hypertrophied lenticels & $\begin{array}{l}\text { Growing in a community } \\
\text { dominated by OBL spe- } \\
\text { cies** }\end{array}$ \\
\hline Heterophylly* & $\begin{array}{l}\text { Growing in a depression with } \\
\text { water-stained leaves* }\end{array}$ \\
\hline Succulent leaves* & $\begin{array}{l}\text { Growing on an undrained hy- } \\
\text { dric soil }\end{array}$ \\
\hline \multicolumn{2}{|l|}{ Succulent roots* } \\
\hline \multicolumn{2}{|l|}{ Fluted trunks } \\
\hline \multicolumn{2}{|l|}{ Multiple trunks in trees* } \\
\hline \multicolumn{2}{|l|}{ Changes in life-form } \\
\hline $\begin{array}{l}* \text { Verification of undrained } \\
\text { in water or saturated soils i } \\
\text { that it is a hydrophyte. } \\
* * \text { Association is an import } \\
\text { cur in wetlands and aquatic } \\
\text { them should be a hydrophy }\end{array}$ & $\begin{array}{l}\text { ils or observation of plant growing } \\
\text { ended for this adaptation to confirm } \\
\text { eration. Since OBL species only oc- } \\
\text { any non-OBL species growing with }\end{array}$ \\
\hline
\end{tabular}

the individual Corps inspector and therefore will not likely be applied consistently. From a professional judgment standpoint, any plant community growing on an undrained hydric soil should be considered a positive indicator of hydrophytic vegetation since the plants are "hydrophytes" in the true sense of the word-plants actively growing in water or under conditions of prolonged anaerobic conditions due to wetness.

The 1989 interagency wetland delineation manual (Federal Interagency Committee for Wetland Delineation 1989) recognized that all plants on the federal wetland plant lists were potential hydrophytes. Similar to the Corps manual, all plants that were FAC or wetter were identified as hydrophytic species, but the 1989 manual ignored the + and - signs, so FAC- species were also included in the basic rule. FACU species were not regarded as reliable indicators of wetlands by themselves, but when they were found growing on hydric soils with evidence of wetland hydrology (e.g., water-stained leaves or oxidized rhizospheres), they were determined to be hydrophytes and satisfied the hydrophytic vegetation criterion of the three-criteria wetland identification approach.

Tiner (1991) explained the current concept of hydrophytes as related to wetland delineation. In our attempts to use plants as indicators of wetland, we must recognize the values as well as the limitations of plants (especially at the species level) and that the plant lists provide a guide to the likelihood that an individual of a given species is a hydrophyte. The actual determination of a plant as a hydrophyte is determined by the environmental conditions under which it is growing.

\section{ACKNOWLEDGMENTS}

I acknowledge the tireless efforts of Buck Reed (U.S. Fish and Wildlife Service, retired) who compiled the wetland plant lists and worked on these lists from the late 1970s until his retirement in 2004, his staff, the work of the national and regional plant panels who reviewed and made decisions on the plant indicator statuses across the country, and all the scientists who have provided comments on the lists. For this paper, I am especially appreciative of the data summaries provided by Andrew Cruz (U.S. Fish and Wildlife Service) and by Misako Nishirno and John T. Kartesz (Biota of North America Project, North Carolina Herbarium at the University of North Carolina, Chapel Hill). Bill Wilen (U.S. Fish and Wildlife Service), Rachel Budelsky (Associate Editor), and two anonymous reviewers provided constructive comments on the manuscript.

\section{LITERATURE CITED}

Barbour, M. G., J. H. Burk, and W. K. Pitts. 1980. Terrestrial Plant Ecology. Benjamin/Cummings Publishing Company, Menlo Park, CA, USA.

Braun-Blanquet, J. 1932. Plant Sociology. The Study of Plant Communities. McGraw-Hill, New York, NY, USA.

Cowardin, L. M., V. Carter, F. C. Golet, and E. T. LaRoe. 1979. Classification of Wetlands and Deepwater Habitats of the United States. U.S. Fish and Wildlife Service, Washington, DC, USA. FWS/OBS-79/31. http://wetlands.fws.gov/Pubs_Reports/Class_ Manual/class_titlepg.htm.

Daubenmire, R. F. 1968. Plant Communities: A Textbook of Plant Synecology. Harper and Row, New York, NY, USA.

Environmental Laboratory. 1987. Corps of Engineers Wetlands Delineation Manual. U.S. Army Engineer Waterways Experiment Station, Vicksburg, MS, USA. Tech. Rep. Y-87-1. http://el.erdc. usace.army.mil/wetlands/pdfs/wlman87.pdf.

Federal Interagency Committee for Wetland Delineation. 1989. Federal Manual for Identifying and Delineating Juridictional Wetlands. U.S. Army Corps of Engineers, U.S. Environmental Protection Agency, U.S. Fish and Wildlife Service, and U.S.D.A. Soil Conservation Service, Washington, DC, USA

Kartesz, J. T. 1994. A Synonymized Checklist of the Vascular Flora of the United States, Canada, and Greenland. Volume I-Checklist, Volume II-Thesaurus. Timber Press, Portland, OR, USA.

Lowe, A., S. Harris, and P. Ashton. 2004. Ecological Genetics. Design, Analysis, and Application. Blackwell Publishing, Oxford, England. 
Michener, M. C. 1983. Wetland site index for summarizing botanical studies. Wetlands 3:180-191.

Reed, P. B., Jr. 1988. National List of Plant Species that Occur in Wetlands: 1988 National Summary. U.S. Fish and Wildlife Service, Washington, DC, USA. Biol. Rep. 88 (24).

Reed, P. B., Jr. (compiler). 1997. Revision of the National List of Plant Species that Occur in Wetlands. In Cooperation with the National and Regional Interagency Review Panels: U.S. Fish and Wildlife Service, U.S. Army Corps of Engineers, U.S. Environmental Protection Agency, and Natural Resources Conservation Service. Department of Interior, U.S. Fish and Wildlife Service, Washington, DC, USA.

Reed, P. B., Jr., D. Peters, J. Goudzwaard, I. Lines, and F. Weinmann. 1993. Supplement to the National List of Plant Species that Occur in Wetlands: Northwest (Region 9). U.S. Fish and Wildlife Service, Washington, DC. Biol. Rep. 88 (26.9).

Sipple, W. S. 1988. Wetland Identification and Delineation Manual. Vol. I. Rationale, Wetland Parameters, and Overview of Jurisdictional Approach. Revised Interim Final. U.S. Environmental Protection Agency, Office of Wetlands Protection, Washington, DC, USA.

Tiner, R. W. 1991. The concept of a hydrophyte for wetland identification. BioScience 41:236-247.

Tiner, R. W. 1993. The primary indicators method-a practical approach to wetland recognition and delineation in the United States. Wetlands 13:50-64.

Tiner, R., R. Lichvar, R. Franzen, C. Rhodes, and W. Sipple. 1995. Supplement to the List of Plant Species that Occur in Wetlands:
Northeast (Region 1). U.S. Fish and Wildlife Service, Washington, DC, USA. Supplement to Biological Report 88 (26.1).

Tiner, R. W. 1999. Wetland Indicators: A Guide to Wetland Identification, Delineation, Classification, and Mapping. Lewis Publishers, CRC Press, Boca Raton, FL, USA.

Turesson, G. 1922a. The species and the variety as ecological units. Hereditas 3:100-113.

Turesson, G. 1922b. The genotypical response of the plant species to the habitat. Hereditas 3:211-350.

Turesson, G. 1925. The plant species in relation to habitat and climate. Hereditas 6:147-236.

U.S. Fish and Wildlife Service. 1996. National List of Vascular Plant Species that Occur in Wetlands: 1996 National Summary. Washington, DC, USA. http://wetlands.fws.gov/bha/download/1996/ national.pdf.

Wentworth, T. R., and G. P. Johnson. 1986. Use of Vegetation in the Designation of Wetlands. North Carolina State University, School of Agriculture and Life Sciences, Raleigh, NC. Report for the U.S. Fish and Wildlife Service's National Wetlands Inventory, St. Petersburg, FL, USA.

Wentworth, T. R., G. P. Johnson, and R. L. Kologiski. 1988. Designation of wetlands by weighted averages of vegetation data: a preliminary evaluation. Water Resources Bulletin 24:389-396.

Williams, A. E. 1992. U.S. Army Corps of Engineers memorandum on clarification and interpretation of the 1987 manual. March 6, 1992. U.S. Army Corps of Engineers, CECW-OR, Washington, DC, USA.

Manuscript received 6 September 2005; revisions received 16 December 2005; accepted 13 February 2006. 